\title{
The Protections Afforded by Geographical Indicators and Their Characteristics: The Case of the Gis in Brazilian Agribusiness
}

\author{
Alan Malacarne ${ }^{1}$, Liaria Nunes da Silva ${ }^{1}$, Camila Souza Vieira ${ }^{1}$, Ricardo Fontes Macedo ${ }^{1}$, Andreia Malacarne ${ }^{2}$, \\ Washington Sales do Monte ${ }^{1} \&$ Robelius De-Bortoli ${ }^{1}$ \\ ${ }^{1}$ Federal University of Sergipe, São Cristóvão, Brazil \\ ${ }^{2}$ Federal University of São João del Rei, São João del Rei, Brazil \\ Correspondence: Alan Malacarne, Federal University of Sergipe, Residencial Universidade Center, Number: 784, \\ Apartment: 204, Street Major Teles de Menezes, Jd. Rosa Elze, CEP: 49100-000, São Cristóvão, Sergipe, Brazil. \\ Tel: 55-027-99801-1662. E-mail: alanmalacarne1988@gmail.com
}

Received: November 22, 2018

Accepted: December 25, 2018

Online Published: February 15, 2019

doi:10.5539/jas.v11n3p541

URL: https://doi.org/10.5539/jas.v11n3p541

The research is financed by FAPITEC-Foundation for Research and Technological Innovation Support of the State of Sergipe.

\begin{abstract}
Geographical Indication (GI) is a way of differentiating a product in the market by highlighting its added value and guaranteed origin. The objective in this paper was to analyze the Brazilian agribusiness GIs in order to identify the extent of the protection in this form of certification. A bibliographic survey was carried out in the public domain as well as a documentary search in the National Institute of Industrial Property (INPI) database. The database of the registries of GIs, comparing the characteristics of the GIs as: Associations and Cooperatives, in natura and modified, direct and manufactured production, animal and vegetable product, and product or service. The data of GIs was collected and grouped. Soon after, a search was conducted on the official sites of the cooperatives and associations in order to gather information about the production and other details. Direct production is very labor intensive and can not be produced in large quantities. The associations and cooperatives that have the IG seal adopt a manufactured production and hope thus have a greater financial return. All of the Brazilian agribusiness GIs are designated for products. This study serves as a basis for future research on GIs that wish to know the characteristics of Brazilian GIs in order to interact on the subject.
\end{abstract}

Keywords: intellectual property, geographical indication, agribusiness, family agriculture, Brazilian agriculture; specialty foods

\section{Introduction}

As Geographical Indications (GIs) have expanded throughout the world as a register that protects the products of small-scale farmers in specific regions (Besky, 2014), they have become one of the areas of industrial property that distinguishes products by their geographical origins (Kan \& Gülçubuk, 2008). GI is a way of differentiating a product in the market through its added value and guaranteed origin (Babcock, 2015). It is also a protection against unfair competition and possible imitations, because once the name of origin is registered, it becomes the official property of that particular region (Vaudour \& Shaw, 2017). According to Vats (2016), GI protection-besides taking into account climatic, geographical and local origin factors-brings socio-cultural benefits such as higher income, job creation, and productivity in the region. In Brazil, the National Institute of Industrial Property (INPI) is responsible for registering GIs of the regions covered by the certification.

The GIs are divided into two different categories, those with Denomination of Origin (DO) and Indication of Provenance (IP). The Denomination of Origin registers a region in which it there exists a product with specific place of origin, taking into account characteristics such as soil, climate and the specific management of production. On the other hand, the Indication of Provenace refers to a product or service that has made a region well-known for its production or supply (INPI, 2018a). These GI registries benefit consumers and producers, since consumers can buy their product knowing that it is legitimate and has a guaranteed origin, thereby avoiding taking home an imitation, while producers gain prominence in the market by owning a differentiated product, 
which improves price and competitiveness (Jena \& Grote, 2010).

GIs can improve not only social and economic sustainability but also help preserve the environment. According to Belletti, Marescotti, and Vakoufaris (2015), IG products do not only take into account the product's impressive qualities, such as aroma and flavor. Rather, there is also an awareness of the ecology and conservation of the environment. In this way, the IG plays an important role in establishing ecologically correct practices in the areas covered by certification.

In the European countries and in the USA, GIs are a well-publicized subject in literature, and it is known among consumers. In Brazil, GIs are still a recent issue, but the number of research studies conducted in recent years has been growing. Aiming to find evidence to examine the Brazilian agribusiness GIs, the objetive this paper is analyzing the Brazilian agribusiness GIs in order to determine what is actually protected in this type of certification.

\section{Material and Method}

The materials and the method used in the present research will be described as follows, specifically identifying the type of research, how the data collection was conducted, and what procedures were used.

\subsection{Research Design}

According to its nature, this research is classified as basic, since it is geared towards the generation of new knowledge. Because of its objectives, the research is characterized as descriptive, as it establishes patterns of data collection techniques. Regarding the problem approach, the research translates the information into numbers as well as an interpretative approach to the reality of the data (Vergara, 1990; Marconi \& Lakatos, 2003; Kauark, Manhães, \& Medeiros, 2010).

\subsection{Data Collection}

A bibliographic survey was carried out in the public domain as well as a documentary search in the National Institute of Industrial Property (INPI) database. The database of the registries of GIs, separated into DO and IP, was accessed, and only the agribusiness GIs granted until the date of April 25, 2018 were collected. The results are presented in a descriptive way, comparing the characteristics of the GIs as: Associations and Cooperatives, in natura and modified, direct and manufactured production, animal and vegetable product, and product or service.

\subsection{Procedures}

First, the data of DOs and IPs was collected and grouped. Soon after, a search was conducted on the official sites of the cooperatives and associations in order to gather information about the production and other details about the GIs. The data was then used to generate graphs for better visualization of the characteristics of the GIs, and thereafter discussed according to the facts and observations of the author.

\section{Results}

The next section will demonstrate all of the Brazilian Agribusiness GIs granted by the INPI until April 2008. These GIs are divided into their two classes, with the DOs being listed in one framework and the IPs in another. Also included are the graphs with the characteristics of DOs and IPs, showing the percentage of each element chosen by the author to be analyzed.

\subsection{List of Brazilian Agribusiness GIs}

Table 1 shows the Brazilian agribusiness DO records granted by INPI. There is a nearly equal quantity of animal and vegetable products. It can be observed that the state of Rio Grande do Sul has two records for wines and sparkling wines. Among all products are honey and propolis that come from the same animal and have three records in total. 
Table 1. Brazilian agribusiness DO registries granted by INPI

\begin{tabular}{|c|c|c|c|}
\hline Product & Geographical Name & Estate & Petitioner \\
\hline Rice & Gaucho North Coast & Rio Grande do Sul & $\begin{array}{l}\text { Association of Rice Producers of the Gaucho } \\
\text { North Coast-APROARROZ }\end{array}$ \\
\hline $\begin{array}{l}\text { Cultured marine shrimp of the } \\
\text { species Litopenaeus Vannamei }\end{array}$ & Costa Negra & Ceará & $\begin{array}{l}\text { Association of the Shrimp Farmers of the } \\
\text { Costa Negra }\end{array}$ \\
\hline Red propolis and red propolis extract & $\begin{array}{l}\text { Manguezais de } \\
\text { Alagoas }\end{array}$ & Alagoas & $\begin{array}{l}\text { Union of the Producers of Red Propolis of the } \\
\text { State of Alagoas }\end{array}$ \\
\hline Wines and sparkling wines & Vale dos Vinhedos & Rio Grande do Sul & $\begin{array}{l}\text { Fine Wine Producers Association of Vale dos } \\
\text { Vinhedos-APOVALE }\end{array}$ \\
\hline $\begin{array}{l}\text { Green coffee grain and industrialized } \\
\text { coffee roasted in grain or ground }\end{array}$ & Cerrado Mineiro & Minas Gerais & Federation of Coffee Growers of the Cerrado \\
\hline Bee Honey-Apis Mellífera & Ortigueira & Paraná & $\begin{array}{l}\text { Association of Ortigueira Honey } \\
\text { Producers-APOMEL }\end{array}$ \\
\hline Green Propolis & $\begin{array}{l}\text { Green Propolis Region } \\
\text { of Minas Gerais }\end{array}$ & Minas Gerais & FEMAP-Mineiro Beekeeping Federation \\
\hline
\end{tabular}

Source: INPI, 2018b.

The IP registries in Brazilian agribusiness granted by INPI can be seen in Table 2. It is noted that GI applicants are divided into associations, cooperatives and federations and councils that make up both associations and cooperatives. Beverages stand out among the products, most of them wines and sparkling wines, followed by coffee and cachaça. It can be observed that the number of IPs is higher than that of DOs.

Table 2. Brazilian agribusiness IP registries granted by INPI

\begin{tabular}{|c|c|c|c|}
\hline Product & Geographical Name & State & Petitioner \\
\hline Wines and sparkling wines & Vale dos Vinhedos & Rio Grande do Sul & $\begin{array}{l}\text { A. P. of Fine Wines of the Vale dos } \\
\text { Vinhedos-APROVALE }\end{array}$ \\
\hline Coffee & Region of Cerrado Mineiro & Minas Gerais & Cons. of the Cerrado coffee growers-CACCER \\
\hline $\begin{array}{l}\text { Cachaça and Bluish composite } \\
\text { brandy }\end{array}$ & Paraty & Rio de Janeiro & $\begin{array}{l}\text { Ass. Of the Producers and Friends of Artisanal } \\
\text { Cachaça from Paraty }\end{array}$ \\
\hline Table Grapes and Mango & $\begin{array}{l}\text { Submedia Valley of the } \\
\text { São Francisco River }\end{array}$ & $\begin{array}{l}\text { Brazilian Northeast } \\
\text { Region }\end{array}$ & $\begin{array}{l}\text { Council of the Union of Assemblies and Coop. } \\
\text { Of Table Grapes and Mangroves of the Lower } \\
\text { São Francisco Valley-UNIVALE }\end{array}$ \\
\hline Wines and sparkling wines & Pinto Bandeira & Rio Grande do Sul & $\begin{array}{l}\text { Pinto Bandeira Fine Wine Producers } \\
\text { Association-ASPROVINHO }\end{array}$ \\
\hline Coffee & $\begin{array}{l}\text { Region of Serra da } \\
\text { Mantiqueira de MGs }\end{array}$ & Minas Gerais & Mantiqueira Coffee Producers Association \\
\hline Cheese & Serro & Minas Gerais & $\begin{array}{l}\text { Association of Artisanal Producers of Serro } \\
\text { Cheese }\end{array}$ \\
\hline Beef and dairy products & $\begin{array}{l}\text { Region of Pampa Gaúcho } \\
\text { da Campanha Meridional }\end{array}$ & Rio Grande do Sul & $\begin{array}{l}\text { Ass. Prod. Meat of the Pampa Gaúcho of the } \\
\text { Southern Campaign }\end{array}$ \\
\hline Confectionery and fruit jams & Pelotas & Rio Grande do Sul & Association of Candy Producers of Pelotas \\
\hline Wines and sparkling wines & Vales da Uva Goethe & Santa Catarina & $\begin{array}{l}\text { Association of Grape Growers and Goethe } \\
\text { Wine }\end{array}$ \\
\hline Cheese & Canastra & Minas Gerais & $\begin{array}{l}\text { Association of Canastra Cheese } \\
\text { Producers-APROCAN }\end{array}$ \\
\hline $\begin{array}{l}\text { Green coffee in grains and } \\
\text { roasted, ground. }\end{array}$ & Norte Pioneiro do Paraná & Paraná & $\begin{array}{l}\text { Specialty Coffees Association of the Norte } \\
\text { Pioneiro do Paraná }\end{array}$ \\
\hline Cocoa beans & Linhares & Espírito Santo & Association of Cacao Growers of Linhares \\
\hline Cachaça & Region of Salinas & Minas Gerais & Salinas Cachaça Producers Association \\
\hline Wines and sparkling wines & Altos Montes & Rio Grande do Sul & $\begin{array}{l}\text { Association of Wine Producers of the High } \\
\text { Mountains }\end{array}$ \\
\hline Coffee & Alta Mogiana & São Paulo & Alta Mogiana Association of Coffee Producers \\
\hline
\end{tabular}




\begin{tabular}{|c|c|c|c|}
\hline Melon & Mossoró & Rio Grande do & Executive Committee on fruit growing of RN \\
\hline Wines and sparkling wines & Monte Belo & Rio Grande do Sul & Monte Belo do Sul Viticultural Association \\
\hline Cajuína & Piauí & Piauí & $\begin{array}{l}\text { Union of Piauí Cashew Associations, } \\
\text { Cooperatives and Producers-PROCAJUÍNA }\end{array}$ \\
\hline Ornamental fish & Rio Negro & Amazonas & $\begin{array}{l}\text { ORNAPESCA-Cooperative P.P.A.P.O.M.A. } \\
\text { Rio Negro }\end{array}$ \\
\hline Cachaça & Microrregião Abaíra & Bahia & $\begin{array}{l}\text { Association of Quality Spirits Producers of the } \\
\text { Abaíra Microregion }\end{array}$ \\
\hline Honey & Pantanal & $\begin{array}{l}\text { Mato Grosso/ } \\
\text { Mato Grosso do Sul }\end{array}$ & $\begin{array}{l}\text { Council of Cooperatives, Associations, } \\
\text { Warehouses and Beekeeping Companies of } \\
\text { Pantanal do Brasil-CONFENAL }\end{array}$ \\
\hline Wines and sparkling wines & Farroupilha & Rio Grande do Sul & $\begin{array}{l}\text { Farroupilhense Association of Sparkling Wine } \\
\text { Producers, Juices and Derivatives-AFAVIN }\end{array}$ \\
\hline Sausage & Maracaju & Mato Grosso do Sul & $\begin{array}{l}\text { Association of Traditional Sausage Producers } \\
\text { of Maracaju-APTRALMAR }\end{array}$ \\
\hline Saffron & Região de Mara Rosa & Goiás & $\begin{array}{l}\text { Mara Rosa Saffron Producers } \\
\text { Cooperative-COOPERAÇAFRÂO }\end{array}$ \\
\hline Guava & Carlópolis & Paraná & $\begin{array}{l}\text { Association of Olive Growers and Fruit } \\
\text { Growers of Carlópolis -APC }\end{array}$ \\
\hline Coffee & Region of Pinhal & São Paulo & $\begin{array}{l}\text { Coffee Council of Mogiana de } \\
\text { Pinhal-COCAMPI }\end{array}$ \\
\hline Yam & $\begin{array}{l}\text { Region of São Bento de } \\
\text { Urânia }\end{array}$ & Espírito Santo & $\begin{array}{l}\text { Association of Yam Producers São Bento do } \\
\text { Espirito Santo-APISBES }\end{array}$ \\
\hline Fine table grapes & Marialva & Paraná & $\begin{array}{l}\text { Association of North Noroeste Paranaense } \\
\text { Fruticulturalists-ANFRUT }\end{array}$ \\
\hline Mate herb & São Matheus & Paraná & $\begin{array}{l}\text { Association of Friends of the Mate Herb of } \\
\text { São Mateus }\end{array}$ \\
\hline Honey & West of Paraná & Paraná & $\begin{array}{l}\text { Agrofamiliar Solidarity } \\
\text { Cooperative-COOFAMEL }\end{array}$ \\
\hline Cassava flour & Cruzeiro do Sul & Acre & $\begin{array}{l}\text { Center of Family Producers' Cooperatives of } \\
\text { Juruá Valley-CENTRAL JURUÁ }\end{array}$ \\
\hline Guaraná & Maués & Amazonas & $\begin{array}{l}\text { Association of Guaraná Producers of Maués } \\
\text { Geographical Indication }\end{array}$ \\
\hline
\end{tabular}

Source: INPI, 2018b.

The percentages of the characteristics of the DOs of Brazilian agribusinesses can be seen in Figure 1. According to the graph, DOs have more associations than co-operatives, when talking about how the product is marketed it can be observed that in natura products are in the majority, while the modified products are less represented. The production of these products is $100 \%$ manufactured, that is, produced on a large scale. As we observed, in the animal and vegetable production the data is approximate, which shows a diverse array among the origins of the products. Regarding the characteristics of the DO between product and service, the graph shows us that there are no service records among the Brazilian agribusiness GIs. 


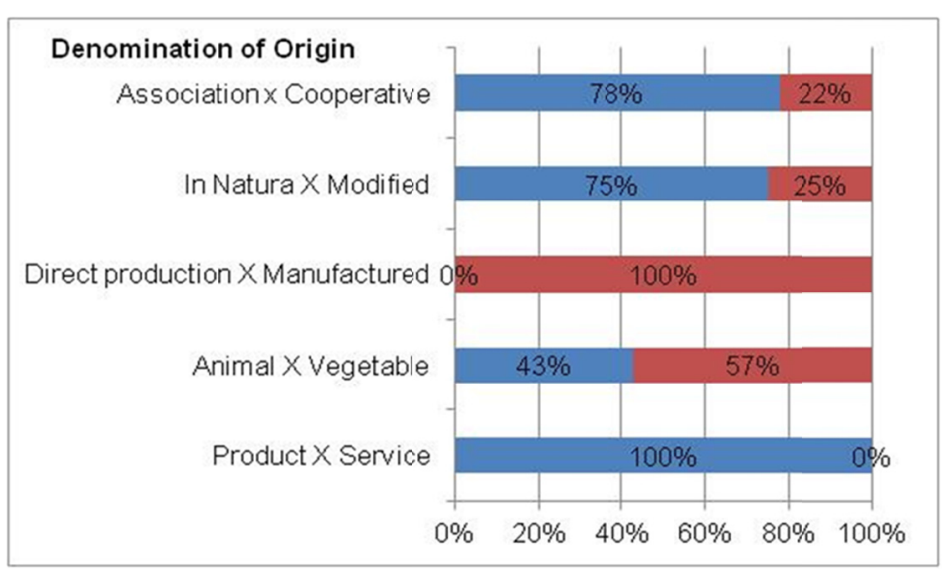

Figure 1. Characteristics of Brazilian agribusiness DO

The data referring to the IPs of in Brazilian agribusiness and their respective characteristics are represented in Figure 2. It is observed that all IP records are for products, not having any service records. In relation to production, almost all products are manufactured goods, including products of plant origin as well as products of animal origin. When we look at the associations and cooperatives, we can see that there are more associations, as opposed to the cooperatives, which represent only a small percentage. And we can see that there are more modified products than in natura products, which is different from what we saw in the DO chart.

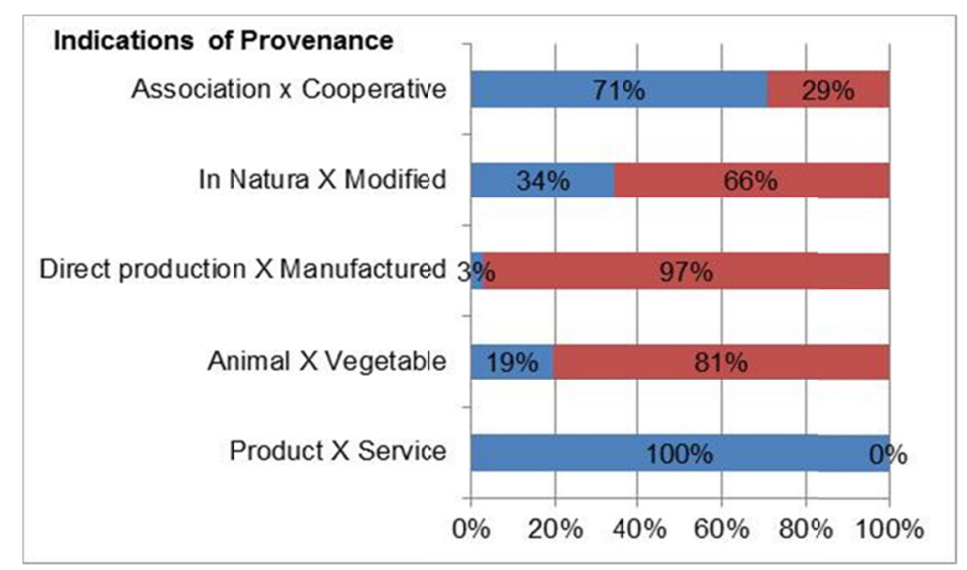

Figure 2. Characteristics of Brazilian agribusiness IP

\section{Discussion}

The Cerrado Mineiro Coffee DO fits into various classifications, such as in the two categories (Association and Cooperative), since it is a Federation that encompasses both. According to studies by Melo (2015) associations are initiatives supported by group resources and efforts to generate benefits for their members, as well as to resolve any problems that may arise, while cooperatives are voluntary organizations with people prepared to assume responsibilities and services as an integral part of the cooperative, generating benefits for all members. The Special Coffee Association of the Norte Pioneiro do Paraná, which has IP certification, is also presented as in natura (green coffee in grains) and Modified (roasted and ground coffee). This shows the variety of possibilities of the same IG, since in the same registry it is possible to vary the way in which the product is presented to resellers and consumers.

The Association of Candy Producers of Pelotas, with an IP for traditional confectionery and fruit jams, is the only product with direct production, that is, not manufactured, with products that use ingredients of animal and vegetable origin. The fact that the production is direct is due to the fact that there is a relatively small number of people working, because in this production the quality and homogeneity of the products is prioritized and not the 
production in large scale. The other products of the Brazilian agribusinesses with IG certifications have manufactured production, enabling them to produce these products in large quantity and in a standardized way. According to Oliveira (2007), direct agricultural production has long been replaced by the production of manufactured goods, since the direct sale of the commodity to the consumer has become almost impossible because of the distance and duration of the trips to deliver the agricultural products. With this, we can note the cause of the predominance of the manufactured products.

The Mineiro Beekeeping Federation (FEMAP), which produces green propolis with a DO, the Council of Associations of Cerrado Mineiro Coffee Growers (CACCER), with an IP for coffee, the Council of the Union of Associations and Cooperatives of Producers of Table Grapes and (UNIVALE) with an IP for table grapes and mangoes, the Council of Cooperatives, Associations, Warehouses and Beekeeping Companies of the Pantanal of Brazil (CONFENAL) with its IP for honey, the Council of the Mogiana de Pinhal Coffee (COCAMPI), with a coffee IP, the Union of Associations and Cooperatives and Producers of Cajuína do Piauí (PROCAJUÍNA) with an IP for Cajuína, are associations and cooperative groups, so they appear in both options in the charts above. They show that GIs encompass a large number of people with common interests, thereby linking the economic interests of cooperatives to the deeper interest of associations that take social, cultural and political interests into account. According to Junqueira and Luengo (2000), it is important for the rural producer to join an association or cooperative, since it facilitates the transition from a simple rural producer to an agricultural entrepreneur who knows the market, invests and negotiates, since acting together with a common interest makes it easier to market the products.

Like the Cerrado Mineiro and Northern Pioneer of Paraná, the Meat Producers Association of the Pampa Gaúcho of the Southern Campaign presents its GI with in Natura (meat) and modified products (derived from meat). This makes it possible to have a variety of products with the same GI label. According to Morais (2017) the variety of food products is a determinant for the success of agribusinesses in countries like Brazil.

Beverages make up the majority in Brazilian GIs, with emphases on wines and sparkling wines, cachaça, and coffee, which is a traditional product in Brazil. Other less well-known beverages are the Maués guaraná in the Amazon that is sold in powder, and the cashew that is perhaps the IG record for the most exotic drink, because it is a species of juice extracted from the mature cashew fruit through pressing, among other processes of production. Cashews, aside from having the certification of GI, is also a cultural heritage of the state of Piauí. According to De Abreu and De Souza (2004), the cashew flavor is determined by several factors, including fruit maturation, the type of pressing used for juice extraction, and the cashew variety.

The Guarana Producers' Association of Maués Geographical Indication in Amazonas produces a large part of the guaraná of the state, the specificity is that this product is made in a $100 \%$ manual way, and even with this simple form of production are produced tons per year of the product. What is an interesting mix of traditional production (since it is made manually) with manufactured production, since standardized products are sold on a large scale. According to Tricaud, Pinton, and Pereira (2016) due to agricultural expansion in the early 1970s, guaraná was losing its link with Amazonian territory, but in the 1990s began a search for agroecological actions and family-based production in order to recover and value the origin of this typical culture of the region that is the production of guarana made manually.

The majority of the Brazilian GIs are of vegetable origin, possessing only 12 records with products of animal origin, these products vary between shrimps, fish, propolis, honey, cheeses, sausage, meat and derivatives. With emphasis on honey and propolis that have the same origin and together total 5 records, it is worth mentioning that when talking about DO products with animal origin are almost half of total records. According to Alves (2016) products of animal origin are negatively affected by stress and inappropriate breeding and slaughter practices, however, the animals that are most naturally created will yield a better product, the GIs especially the DOs have controlled origin and production, and sustainable practices and ecologically correct, which guarantees the quality of the product.

When discussing the characteristics of the GI record in products or services, we observe that the GIs in agribusinesses have no records listed as services, they are all products. Brazil only has one service registry throughout the country, which was founded in the Management Center of the Digital Port of the state of Pernambuco. This center provides information and communication technology services through development, maintenance and support, and is an IP (INPI, 2018b).

The fact that Brazil only has 7 DO records and 34 agribusiness PI records shows that investment in the quality of agriculture is still going on in the country, since European countries with much smaller size agribusinesses have numerous GI records for this category. It is interesting to note that an OD record is much more difficult to obtain 
than an IP record, since factors unique to the producing region are taken into account, while IP registration only takes into account the reputation of the region where the goods are produced. According to Moncayo, Rosales, Izquierdo-Hornillos, Anzano, and Caceres (2016), DO is one of the most important means of protecting and controlling the production and origin of agriculturally-produced food products. The only Brazilian regions that have both records for their products are the Cerrado Mineiro Region that produces coffee in Minas Gerais and the Vale dos Vinhedos Region that produces wines and sparkling wines in Rio Grande do Sul and is the pioneer of IG in the Brazil, it is not by chance that these two states have the most GI records in Brazil, for a total of 9 records in Rio Grande do Sul and 7 in Minas Gerais.

It can be concluded that the GI registers, both of DO and of IP have several characteristics in which they are similar, and others in which they differ. In discussing the registrants, that is, the group of people who applied for GI registration, there is a predominance of associations as opposed to the cooperatives, which demonstrates that in most cases, all of the members of a GI demarcated region have equal responsibilities and gains, because in cooperatives, members have specific obligations and gains.

An interesting difference between DOs and IPs is the way in which the product is presented to the consumer, while most of the IP products are modified, the DOs are mostly in natura, which shows that DO products have a more controlled and specific production process, which is one of the requirements that INPI requires for the registration term. Another distinct specificity is the origin of the GI, whereas in the IPs the highest percentage of the products are of vegetable origin, in the DOs the products are divided between animal and vegetable origin. This demonstrates that the products of vegetable origin in Brazil are more well-known as being reputable sources, while it is currently more difficult to register a product of animal origin.

The production of GIs is almost $100 \%$ manufactured. Among both types of records there was only one IP with direct production, that of the candy producer in region of Pelotas. Direct production is very labor intensive and can not be produced in large quantities, so associations and cooperatives that have the IG seal adopt a manufactured production so that they can produce on a large scale and thus have a greater financial return.

All of the Brazilian agribusiness GIs are designated for products, not having any for service, which shows an opportunity for a new type of agribusiness GI, a record that is for a specific service in the rural environment. This study serves as a basis for future research on GIs, both for Intellectual Property scholars, and for associations and cooperatives that wish to know the characteristics of Brazilian GIs in order to interact on the subject and have a theoretical basis for a future application registration with the INPI.

\section{References}

Alves, A. R., Júnior, J. P. F., Santana, M. H. M., de Andrade, M. V. M., Lima, J. B. A., da Silva Pinto, L., \& de Medeiros Ribeiro, L. (2016). Efeito do estresse sobre a qualidade de produtos de origem animal. PUBVET, 10, 448-512. https://doi.org/10.22256/pubvet.v10n6.448-459

Babcock, B. A. (2015). Geographical indications, property rights, and value-added agriculture. Iowa Ag Review, 9(4), 1.

Belletti, G., Marescotti, A., Sanz-Cañada, J., \& Vakoufaris, H. (2015). Linking protection of geographical indications to the environment: Evidence from the European Union olive-oil sector. Land Use Policy, 48, 94-106. https://doi.org/10.1016/j.landusepol.2015.05.003

Besky, S. (2014). The labor of terroir and the terroir of labor: Geographical Indication and Darjeeling tea plantations. Agriculture and Human Values, 31(1), 83-96. https://doi.org/10.1007/s10460-013-9452-8

De Abreu, F. A. P.; De Souza, A. C. R. (2004) Cajuína: como produzir com qualidade. Embrapa Agroindústria Tropical-Documentos (INFOTECA-E), 95, 9-34.

INPI (Instituto Nacional de Propriedade Industrial). (2018a). Indicação Geográfica no Brasil. Retrieved from http://www.inpi.gov.br/menu-servicos/indicacao-geografica/indicacao-geografica-no-brasil

INPI (Instituto Nacional de Propriedade Industrial). (2018b). Pedidos de indicação geográfica concedidos e em andamento. Retrieved from http://www.inpi.gov.br/menu-servicos/indicacao-geografica/pedidos-de-indica cao-geografica-no-brasil

Jena, P. R., \& Grote, U. (2010). Changing institutions to protect regional heritage: A case for geographical indications in the Indian agrifood sector. Development Policy Review, 28(2), 217-236. https://doi.org/ $10.1111 / \mathrm{j} .1467-7679.2010 .00482 . \mathrm{x}$

Junqueira, A. H., \& Luengo, R. D. F. A. (2000). Mercados diferenciados de hortaliças. Horticultura Brasileira, 18(2), 95-99. https://doi.org/10.1590/S0102-05362000000200003 
Kan, M., \& Gülçubuk, B. (2008). Kırsal ekonominin canlanmasında ve yerel sahiplenmede coğrafi işaretler. $U \ddot{U}$ Ziraat Fakültesi Dergisi, 22(2), 57-66.

Kauark, F. S., Manhães, F. C., \& Medeiros, C. H. (2010). Metodologia da pesquisa: Um guia prático. Itabuna: Via Litterarum.

Melo, W. P. (2015) Associação e cooperativa de produtores rurais. Retrieved from http://www.ceplac.gov.br/ Agrotropica/semfaz/28semfaz_caderno2.pdf

Moncayo, S., Rosales, J. D., Izquierdo-Hornillos, R., Anzano, J., \& Caceres, J. O. (2016). Classification of red wine based on its protected designation of origin (PDO) using Laser-induced Breakdown Spectroscopy (LIBS). Talanta, 158, 185-191. https://doi.org/10.1016/j.talanta.2016.05.059

Morais, L. S. (2017). Avaliação das características fisico químicas do Passiflora cincinnata em condições ambientes e refrigeradas (24 f. Course Completion Work (Graduation in Agribusiness Management), College UnB Planaltina, University of Brasília, Distrito Federal).

Oliveira, A. U. (2007). Modo de Produção Capitalista, Agricultura e Reforma Agrária. São Paulo: FFLCH.

Tricaud, S., Pinton, F., \& Pereira, H. D. S. (2016). Local knowledge and practices of guarana producers (Paullinia cupana Kunth var. sorbilis) on the middle Amazon: Two grassroots organizations confronting innovation. Boletim do Museu Paraense Emílio Goeldi. Ciências Humanas, 11(1), 33-53.

Vats, N. K. (2016). Geographical Indication-The factors of Rural Development and Strengthening Economy. Journal of Intellectual Property Rights, 21, 347-354.

Vaudour, E., \& Shaw, A. B. (2017). A worldwide perspective on viticultural zoning. South African Journal of Enology and Viticulture, 26(2), 106-115. https://doi.org/10.21548/26-2-2125

Vergara, S. C. (1990). Tipos de pesquisa em administração. São Paulo: Atlas.

\section{Copyrights}

Copyright for this article is retained by the author(s), with first publication rights granted to the journal.

This is an open-access article distributed under the terms and conditions of the Creative Commons Attribution license (http://creativecommons.org/licenses/by/4.0/). 